\title{
Życie ze śmiercią języka. Pisanie jako rodzaj terapii. Przypadek wilamowski - mój przypadek
}

DOI: http://dx.doi.org/1 0.12775/LC.2019.030

Ich habe mir nie vorgenommen, zu schreiben. Ich habe damit angefangen, als ich mir nicht anders zu helfen wusste.

Herta Müller

ęzyk wilamowski jest językiem literackim. Pisali w nim Fliöera-Fliöera (Florian Biesik, 1851-1926), Freślik-Jáśki (Jan Kuczmierczyk, 1880-1961) i Tołer-Jüza (Józef Gara, 1929-2013). Pisało, czy może lepiej, układało w nim rymy wielu anonimowych Wilamowian, którym zawdzięczamy powstanie wierszy, pieśni, wyliczanek. Ich autorzy tworzyli w różnych warunkach. Zarówno Fliöera, jak i Jüza (tego ostatniego osobiście znałem) zaczęli pisać pod koniec życia, chcąc przekazać coś potomnym.

Ja zacząłem pisać, gdy byłem w szkole podstawowej. Nie piszę tego tutaj, żeby się pochwalić, jaki wtedy już byłem oświecony. Wręcz przeciwnie - podobnie jak u Herty Müller, której słowa zacytowałem na początku, nadszedł w moim życiu moment, w którym sobie już nie radziłem. Nie radziłem sobie z atakującą mnie z każdej strony obcością. Lecz nie była to obcość, która chciała pokazać mi, jak wygląda inna kultura, lecz obcość, która chciała

\footnotetext{
* Doktorant w Instytucie Slawistyki Polskiej Akademii Nauk. Aktywista na rzecz rewitalizacji języka wilamowskiego, wilamowianin, członek Stowarzyszenia „Wilamowianie".

E-mail: wymysojer@gmail.com | ORCID: 0000-0003-1408-6530.

1 „Nigdy nie zakładałam, że będę pisać. Zaczęłam to robić, ponieważ nie wiedziałam, jak inaczej sobie pomóc". Tłumaczenie własne.
} 
mnie wciągnąć, zmusić do kolaboracji, a gdy jej się to nie udało, obcość, która chciała zniszczyć to, skąd pochodzę, to, co mi bliskie.

Zacząłem więc pisać. Moje pierwsze próby były to jakieś małe wierszyki czy piosenki, których już dzisiaj nie pamiętam. Nieważna jest według mnie dzisiaj ich treść, lecz sam fakt, że i dlaczego powstały. Powstały w samoobronie przed polską szkołą, polską polityką, polskocentryczną historią. I właściwie, mimo iż na przestrzeni tych kilkunastu lat sięgałem po różne rodzaje i gatunki literackie, w każdym moim utworze jest większy lub mniejszy pierwiastek broniący przed zmuszeniem do asymilacji, do bycia takim jak wszyscy, jak Polacy dookoła, do spolszczenia Wilamowic.

\section{Co mnie dotknęło najbardziej}

To, że próbowano na siłę zrobić ze mnie Polaka, nie wywarło na mnie jednak większego wrażenia. Podobnie Niemcy próbowali z Wilamowian zrobić Niemców. Czytając teksty niemieckich ludoznawców, odnosi się wrażenie, że niemieckość Wilamowic jest oczywista, a Wilamowianie tylko zbłądzili, przekabaceni przez polskich propagandzistów. Z drugiej strony Polacy piszą o odwiecznie polskich Wilamowicach, których niemieccy aktywiści przeciągnęli na swoją stronę.

Do takiego typu narracji, udowadniającej, kim Wilamowianie są, byłem już przyzwyczajony. Zresztą od strony matki jestem Górnoślązakiem, a od strony ojca Ślązakiem Cieszyńskim (czyli Cezarokiem). Także co do tych etniczności ideolodzy niemieccy, polscy i czescy wyrażają różne zdania i sądy, uważając, że są bardziej uprawnieni od samych Ślązaków do ustalania ich narodowości.

Co dotknęło mnie najbardziej, to przemilczanie, umniejszanie tego, co wielu Wilamowian wycierpiało po wojnie. Także upokarzanie Wilamowian publicznie, poprzez jednostronne i tendencyjne wystąpienia, komentarze, teksty. Brak zrozumienia, w jakiej sytuacji stanęli oni w 1939 roku, brak chęci poznania, czym były tak naprawdę volkslisty, niechęć do zagłębienia się w biografie Volksdeutschów. Mówienie o cierpiących po wojnie wilamowskich dzieciach, że były karane słusznie, bo ciążyła na nich odpowiedzialność zbiorowa; ale z drugiej strony nazywanie oprawców komunistami, a nie Polakami, bo przecież komunista to nie Polak.

Znam życiorysy ludzi, których prześladowano. Znam krzywdy, jakich doznali. Znam wiele powojennych historii. Znam dokumenty, które je potwierdzają. Znam kontrargumenty osób, które prześladowały. Znałem osoby, które były ofiarami. Przejście z czasu teraźniejszego (znam) do przeszłego (znałem) w tym wypadku jest niestety uzasadnione: znałem, bo ci ludzie już nie żyją. I nie mogą się bronić. Zresztą rzadko się bronili, usuwając się w cień i pozwalając innym się wypowiedzieć, mówiąc: łö di gyśájta Pöła zih oüskuza ('pozwól tym mądrym Polakom się wygadać'). 


\section{Jak sobie pomóc}

To poczucie niesprawiedliwości, może etnocentryczne, lecz jednak w pewnym sensie odczuwane przeze mnie jako osobę trzecią poczucie krzywdy i niesprawiedliwości nie dawało mi spokoju. Zresztą dalej mi tego spokoju nie daje. Nie mogłem iść na ulicę i krzyczeć, zresztą co by to dało. Opowiadanie o tych historiach różnym ludziom, praca u podstaw, zaznaczanie tego $\mathrm{w}$ wywiadach prasowych o Wilamowicach, pisanie o tym w moich pracach naukowych. To wszystko uważam za odpowiednie. Działania te jednak pomagają zrozumieć te zjawiska innym, nie pomagają bezpośrednio mnie. Nie zrezygnowałem z nich jednak, o czym świadczy projekt naukowy na temat prześladowań Wilamowian, który zdecydowałem się prowadzić2.

Nie wiedziałem, jak sobie pomóc. Wziąłem kartkę i zacząłem pisać. I tak stwierdziłem, że takie pisanie w pewnym sensie mi pomaga. Zastanawiałem się na początku, czy ktoś to będzie czytał. Dalej zastanawiam się, czy ktoś to będzie czytał. Im dłużej piszę, tym mniej jestem przekonany, że tak będzie, ale też tym mniej jest to dla mnie ważne, mniej się tym emocjonuję.

\section{Co, jak i kiedy piszę}

W 2008 roku, kiedy chodziłem jeszcze do gimnazjum, zacząłem pisać pamiętnik. Częściej, niż opis tego, co się działo, były to moje przemyślenia. Niektóre zapiski wyglądały bardziej jak notatka z etnograficznych badań terenowych (choć o metodologii badań etnograficznych jeszcze wtedy nic nie wiedziałem) niż typowa kartka z pamiętnika. Czasami pisałem też wiersze i to one w sumie stanowią największą część mojej twórczości.

Piszę nieregularnie, najczęściej kiedy jestem samotny lub coś mnie dotyka. Nie mam na pisanie też specjalnego „parcia”: moje wiersze trafiają do szuflady, gubią się, nie przywiązuję do nich większej wagi. Jedynym moim utworem (akurat epickim), który został opublikowany w książkowej formie jest S'ława fum Wilhelm, czyli Życie Wilhelma, które jest według mnie jednym z moich słabszych tekstów. Został on napisany w latach 2008-2009, a wydany w roku 2011 przez Stowarzyszenie „Wilamowianie”. Książka trafiła do wielu domów w Wilamowicach, lecz nie wiem, czy i przez kogo została przeczytana. Przyjęta została jednak dobrze, myślę, że dzięki oprawie graficznej i archiwalnym fotografiom, na których Wilamowianie poznali swoich krewnych.

Smutek to uczucie, które w pewnym sensie napędza moją twórczość. Kiedy zmarła moja gyśpon ${ }^{3}$ Linküś-Ruzła (Rozalia Hanusz, 1926-2009) napisałem dwanaście utworów nazwanych przeze mnie Trena nöm Linküś-Ruzła. Śmierć niestety spotyka się często, kiedy ma się wielu znajomych w podeszłym wieku.

\footnotetext{
2 Mowa o projekcie Góry, pagórki, przykryjcie nas - Wilamowianie wobec powojennych prześladowań, finansowanym w ramach programu "Diamentowy Grant” (2016-2020).

3 Wilamowskie określenie przyjaciela, które wywodzi się od określenia partnerów w sprzęganiu koni.
} 
Czasami coś, co napiszę, przesyłam znajomym. Tak było w przypadku powieści Wandyn una cyl, nieco depresyjnej i obfitującej w postacie popełniające samobójstwa. Jest to najdłuższy mój utwór pisany prozą (oprócz wspomnianego pamiętnika, liczącego około sześćset pięćdziesiąt stron rękopisu). Akcja rozgrywa się w Wiedniu i w Wilamowicach, Wiedniu dziewiętnastowiecznym, fikcyjnym, zrekonstruowanym z fotografii, dokumentów i opowieści Wilamowian. Powieść powstała w 2015 roku.

Trudno mi powiedzieć, czy byłem kiedyś dumny z napisania czegoś. Bardziej dumny jestem z mojej pracy w znaczeniu godzin poświęconych na rozmowy z ludźmi, nagrywanie wywiadów, pisanie prac naukowych, słownika języka wilamowskiego. Jeśli chodzi o utwory literackie, jak już wspomniałem, nie przywiązuję do nich większej wagi. Jeśli jednak faktycznie miałbym podać któryś jako powód do dumy, byłby to zbiór Troürikjy Koland z 2013 roku. Są to kolędy wilamowskie, polskie i niemieckie, wszystkie jednak w języku wilamowskim i z nieco zmienionymi tekstami, tak by opowiadać o powojennej historii wilamowskich rodzin. Tak np. słowa kolędy O Gwiazdo Betlejemska brzmią nie O Máj Betlejemśtamła, lecz O Màj Syberyjśtamta.

Cieszę się też, kiedy któryś z moich utworów okazuje się przydatny dla innych. Tak jest np. z tekstami, które wykorzystywane są przez Zespół Regionalny „Wilamowice”, zwłaszcza teksty kolęd, jak Engl kjyta gyziöet höt z 2007 roku, która śpiewana jest już nawet przez grupy kolędnicze niezwiązane z żadnym z wilamowskich zespołów folklorystycznych. Dotyczy to niestety małej części moich utworów.

W związku z powstaniem wilamowskojęzycznej grupy teatralnej, związanej ze Stowarzyszeniem „Wilamowianie” oraz wspieranej przez czuwających nad rewitalizacją wymysiöeryś naukowców z Wydziału „Artes Liberales” Uniwersytetu Warszawskiego, potrzebne są teksty scenariuszy. Wraz z Justyną Majerską-Schneider, jej mężem Rafałem Schneiderem oraz wieloma innymi młodymi Wilamowianami, których wszystkich nazwisk tu nie jestem w stanie wymienić, pisałem scenariusze spektakli, takich jak: Der Kliny Fjyśt, Der Hobbit. Hejn án cyryk oraz Ufjer wett ${ }^{4}$. To, że nie robiłem ich sam, a w każdym kolejnym miałem coraz mniejszą rolę, bardzo mnie cieszyło. Nie tylko dlatego, że z każdym spektaklem spadała ze mnie część odpowiedzialności, ale również dlatego, że według mnie stawały się one coraz lepsze.

\section{Co dalej?}

Obecnie przebywam w Wiedniu. Nie jest to Warszawa, gdzie język wilamowski jest obecny na Uniwersytecie. Nie jest to też Kraków, gdzie czułem się przytłoczony i wyczuwałem w powietrzu ksenofobię. Nie są to Wilamowice, gdzie czuję się w domu. Nie jest to hamyt.

Ojczyzna, rozumiana po niemiecku zarówno jako Vaterland, jak i Heimat, wielokrotnie zawodzi (choć ta druga zawodzi mnie znacznie rzadziej niż ta pierwsza i rzeczami o mniejszym kalibrze, to rozczarowania nią bardziej mnie bolą). Heimweh i Sehnsucht dopadały mnie przez trzy lata moich studiów w Krakowie oraz dwa lata w Warszawie. Zarówno wtedy,

\footnotetext{
${ }^{4}$ Mały Ksiqżę, Hobbit. Tam i z powrotem oraz Na tamtym świecie. O spektaklach tych pisze w swoim artykule również Wicherkiewicz.
} 
jak i podczas mojego obecnego pobytu w najbardziej wilamowskim (poza Wilamowicami oczywiście) europejskim mieście, mój müterśpröh, język wilamowski, pomagał i pomaga mi się odnaleźć w różnych warunkach. To on jest miejscem, w którym zapisane są wszystkie moje najważniejsze wspomnienia. Dlatego też będę pewnie pisał kolejne utwory, zapewne o różnym charakterze. Wszystkie jednak będą po wilamowsku i będą się do Wilamowic odnosić.

Dlatego na koniec znów zacytuję Hertę Müller: Sprache ist keine Heimat, man nimmt eine Sprache ja mit in ein anderes Land.

\section{Moja bibliografia}

\section{Prace naukowe i popularyzatorskie}

2009. Strój wilamowski. Redakcja i opracowanie Tymoteusz Król; tekst i konsultacja naukowa Elżbieta Teresa Filip. Wilamowice: Stowarzyszenie „Wilamowianie”.

2011. „Wilamowice - język, kultura i strój”. W: Antoni Barciak (red.). Realia życia codziennego $w$ Europie Środkowej ze szczególnym uwzględnieniem Śląska. Katowice-Zabrze: Studio Noa Ireneusz Olsza. 459-466.

2013. „Strój ludowy czy kostium zespołu folklorystycznego? Funkcje współczesnego stroju wilamowskiego". W: Anna Weronika Brzezińska, Mariola Tymochowicz (red.). Stroje ludowe jako fenomen kulturowy. Atlas Polskich Strojów Ludowych. Wrocław: Polskie Towarzystwo Ludoznawcze. 111-118.

2013. Tymoteusz Król, Alexander Andrason. „Materials for the Vilamovicean Dictionary- the letter Z". Annales Neophilologiarum 7: 5-29.

2013. Die Wilmesauer - wie Identität weh tun kann. Deutsche Gesellschaft. http://www.deutschegesellschaft-ev.de/pdfs/Tymoteusz\%20Krol-\%20Wilmesau.pdf [dostęp: 15.10.2017].

2014. „Śmiergust wilamowski. Stan badań”. Artes. Prace roczne studentów Międzywydziałowych Indywidualnych Studiów Humanistycznych: 150-185.

2014. Tymoteusz Król, Alexander Andrason. „A fuzzy model of the Vilamovicean language”. Zeszyty Łużyckie 48: 265-292.

2014. Tymoteusz Król, Alexander Andrason. „A contribution to the documentation of a nearly extinct language - Present Tense morphology in Modern Vilamovicean". Studia Linguistica 33: 7-22.

2014. „Ginący język i kultura Wilamowic”. W: Lech Michał Nijakowski (red.). Europejskie i regionalne instrumenty ochrony języków zagrożonych. Warszawa :Wydawnictwo Sejmowe. 77-87.

2014. Tymoteusz Król, Alexander Andrason. „Description of the pronominal system of Modern Vilamovicean". Brünner Beiträge zur Germanistik und Nordistik 28: 93-122.

2014. „Fenomen języka i kultury Wilamowic”. W: Stanisław Durczok, Marcin Niesporek (red.). Pielgrzym, duszpasterz, profesor. Księga jubileuszowa dedykowana Księdzu Profesorowi Janowi Góreckiemu w 70. rocznicę urodzin. Katowice: Drukarnia Archidiecezjalna.

2015. Tymoteusz Król, Justyna Majerska fum Biöetuł, Tomasz Wicherkiewicz. Ynzer jyśty wjytta [Nasze pierwsze słówka]. Stownik obrazkowy języka wilamowskiego. Warszawa: Wydział „Artes Liberales” UW.

2016. Tymoteusz Król, Justyna Majerska fum Biöetul, Tomasz Wicherkiewicz. Heći-peći. Podręcznik do nauki języka wilamowskiego. Warszawa: Wydział „Artes Liberales” UW. 
2016. Tymoteusz Król, Alexander Andrason. A grammar of Wymysorys. Duke University Slavic and East European Language Resource Center - SEELRC. Publikacja on-line dostępna na stronie: https://slaviccenters.duke.edu/uploads/media_items/wymysorys-grammar.original. pdf.

2016. Tymoteusz Król. „Czym jest dla dzisiejszych Wilamowian język wilamowski? Różne funkcje, różne postawy językowe”. Łódzkie Studia Etnograficzne 55: 241-260.

2017. Tymoteusz Król, Justyna Olko i Tomasz Wicherkiewicz. „Awakening the language and speakers' community of Wymysiöeryś'. European Review 26 (1): 179-191. Opublikowany online 10 listopada 2017. Publikacja papierowa: luty 2018.

\section{Utwory niepublikowane (wybór)}

Utwory wierszem

2009-2019. Wiersze i piosenki w Gydenkbihła (Pamiętniku, zob. Teksty pisane prozą).

2009. S'Wilhelms Tut (Śmierć Wilhelma). Druga część historii Wilhelma - niedokończona.

2013. Teksty kolęd:

Hoüt y Betlejem (Dzisiaj w Betlejem)

Wen gybün ej Neźü (Gdy się Chrystus rodzi)

Kuwer oly füt cym krypta (Pójdźmy wszyscy do stajenki)

Köma o śun uf Betlejem dy kjyta (Przybieżeli do Betlejem pasterze)

Yr śtyl fum nahtta (Wśród nocnej ciszy)

Öemüsik krypta (Ach ubogi żłobie)

2013. Dy Troürikjy Koland (Smutna Kolęda) [zbiór utworów]:

Gyzànt zuła zäjn... (Błogosławieni)

Dy Troürikjy Koland (Smutna kolęda)

Styly naht (Cicha noc)

Zäjt gybata, ny hot frejwuł (Prosimy was, nie miejcie pretensji)

218

Pater, foter (Proszę księdza)

Jyr kyndyn (Wy dzieci)

Wi Płaćnik-baba (Gdy Płaćnik-babka)

S'köma ju y ynzyś hytta (Przybieżeli do naszego domku)

Hoüt y Wymysoü (Dzisiaj w Wilamowicach)

Franuś mytum Nüsú (Franuś z Nusią)

O máj Syberyjśtamta (O gwiazdo syberyjska)

O babela (O babciu)

O öemuśik krypła (O biedna stajenka)

Diöh dy wàjsa śtrösa (Poprzez białe drogi)

Máj liwys kacta (Mój kochany kotku)

War ej śytik? (Kto jest winny?)

S’Brymabjerśtroühta (Krzaczek ostrężnicy)

Wymysiöejer Uralzyn (Wilamowscy synowie Uralu)

Syberyjbüwa (Chłopcy z Syberii)

Jungy Pulk (Młoda Polka)

Kudowa (Kudowa)

Dy Kjyc (Krzywda)

Trynk à kjetih (Pij ten kielich)

Nynder mäj Göt cy Djyr (Być bliżej Ciebie chcę) 
Wos nö àm tyhter błäjt (Co zostaje poecie?)

Ufum Ruztas grop (Na Rózinym grobie)

Śłöf mäj Ruzła fest (Śpij, moja Ruzło mocno)

Dy Ferftuga cäjt (Przeminiony czas)

Ferśidnikjy fremdhäjt (Różna obcość)

S'Ława àn der Gława (Życie i wiara)

Jernikjy śtrezut (Błądzący tatarak)

Wymysiöejer noükultür (Nowowilamowska kultura)

Göt kymt uf dy wett troürikjy (Bóg przychodzi na świat smutny)

Der Mönd hyndyn gywylkja (Księżyc za chmurami)

2014. Wiersze.

Dy gybjygja (Góry)

S'woser (Woda)

S'otdy tiwa (Stara miłość)

Ufer śpyc (Na szczycie)

Der Fjywyt (Wiosna)

S'Läjbela (Lajbik)

S’Dry (Zakręt)

S'Ława (Życie)

2019. Menćtikkäjt. Zbiór wierszy.

Teksty pisane prozą

2009-2019. Gydenkbihta. Pamiętnik z kilkudziesięcioma wierszami i piosenkami, ok. 1000 stron.

2015. Wandyn una cyt (Wędrówka bez celu). Opowiadanie o losach Wilamowiana, który wyjechał do Wiednia; 50 stron.

2018. S’Friza. Opowieść o fryzyjskiej wyspie w VI w., 29 stron.

Dramaty

2012. Ufum kjyhüf (Na cmentarzu). Niedokończony.

2014. Ufs griny groz (Na zieloną trawę). Dramat napisany nad Jeziorem Klimkówka, ok. 30 stron.

2017. Dy Wymysiöejer Kumedyj (Wilamowska komedia). Niedokończony. 